\title{
THE EFFECTIVENESS OF INVESTMENT INCENTIVES \\ IN THE TURKISH MANUFACTURING INDUSTRY
}

\section{Halit Yanikkaya, Hasan Karaboga*}

\begin{abstract}
This study investigates the impact of investment incentives on sectoral labour productivity, capital intensity, employment and total factor productivity using data on sixteen manufacturing industry sectors in Turkey during the post-liberalization period. To deal with potential endogeneity of the investment incentives, we apply the system GMM estimation technique to the panel dataset for six five-year periods between 1981 and 2009. Our overall GMM estimations indicate that we fail to find any evidence that investment incentives positively affect anyone of our macroeconomic variables. While investment incentives do not increase the employment growth and total factor productivity growth significantly, they significantly reduce the growth rate of value added per work hour and capital stock per work hour. Given that since the early years of the Turkish Republic, investment incentive systems have always been an important part of the industrialization policies; our results have essential implications for the design and effectiveness of investment incentives.
\end{abstract}

Keywords: investment incentives, employment, output, productivity, panel data analysis JEL Classification: $\mathrm{H} 25, \mathrm{O} 38, \mathrm{R} 0$

\section{Introduction}

As policy instruments of the governments, investment incentives mainly aim to affect investment decisions of the firms. Incentives are intended to raise investments, which may ultimately improve certain macroeconomic indicators such as employment, output, labour productivity, and total factor productivity. While they are powerful policy tools both in the developed and developing countries, investment incentives are not the distinctive way of the development; mostly, we can treat them only as a regulatory instrument of economic policies of the government. Because, economic development plans can be achieved only if all policy instruments are in accordance with each other. Moreover, overall policymaking efficiency, economic environment and social infrastructure of the countries determine the investment decisions and returns on investment.

Since the beginning of the Turkish Republic, industrialization policies have always entailed a form of investment incentives (such as the Law of Encouragement of Industry and so on). Investment incentive system has been changed and revised various times in Turkey, and it has been rendered compatible to the condition of different periods. Because of their costs to the budget and political side of the issue, the system and the effectiveness

\footnotetext{
* Halit Yanikkaya, Department of Economics, Gebze Technical University, Gebze/Kocaeli, Turkey (halityanikkaya@gtu.edu.tr);

Hasan Karaboga, Department of Economics, Gebze Technical University, Gebze/Kocaeli, Turkey (hkaraboga@gtu.edu.tr).
} 
of the investment incentives have always become a matter of public debate. Thus, the effectiveness of these policies becomes significant more than ever.

A number of studies examine the effectiveness of the investment incentives. Both theoretical and empirical studies on this subject report very diverse results. However, there is a lack of comprehensive work analysing the impacts of investment incentives in Turkey. Considering sixteen manufacturing industry in Turkey for the years between 1981 and 2009, our study examines the impacts of investment incentives on the growth of sectoral labour productivity, capital intensity, employment, and total factor productivity. We employ the WLS and the system GMM estimation techniques to the panel dataset for six fiveyear periods between 1981 and 2009. Contrary to the expectations, investment incentives significantly reduce labour productivity growth and capital intensity growth, whereas they do not have any significant effect on the growth rates of sectoral employment and total factor productivity growth. Our estimation results thus imply that investment incentives have negative effects or at best have no positive effects on these macroeconomic variables. Our study also contributes to the literature by utilizing more comprehensive and a detailed dataset and also by employing the latest panel data estimation methods to deal with number of econometric problems.

This paper is organized as follows: Section 2 reviews the literature on the impact of the investment incentives. In Section 3, we explain our methodology and specify our data. Finally, Section 4 discusses empirical results of the regressions, and Section 5 concludes the subjects discussed in the paper.

\section{Literature Review}

In the related literature, there are a large number of studies investigating the effects of investment incentives on capital accumulation, employment, and productivity. By providing investment incentives, governments aim to raise economic growth in sectoral, regional, and national levels. The logic is simple; an increase in investment hopefully causes more capital accumulation, creates new employment opportunities, and improves productivity, and so leads to economic growth and welfare. Nevertheless, this objective per $s e$ is not sufficient in obtaining sustainable growth and welfare effects.

A number of studies examine the effects of investment incentives on investment decision of firms to accumulate capital to specific sectors and regions. These studies conclude that investment incentives have at least some effects on the decision of the firms in terms of investment amount and location; firms consider the investment environment, incentive method of the government, and decision of the firms, which may differ from country to country. For instance, using survey data on UK manufacturing firms, Alam and Stafford (1985) find that tax incentives have a negligible impact on firms' investment decisions. Buss (2001) provides a literature review of the studies concerning with the impacts of tax incentives on investment decisions of the firms. He claims that the literature gives insufficient advice to policy makers for economic development. Moreover, he states that researchers do not give any definite information to firms to invest in specific regions and businesses. 
Recently, Cannari et al. (2006) find that investment incentives are not effective to raise investments in the Italian manufacturing industries. Tekin (2006) argues that tax incentives economically useful in the presence of market failures and intensive tax competition, but cost efficiency of the incentives should not be disregarded. Chen et al. (2015) state that private domestic firms in China are attracted to raise investment through tax incentives.

Regarding the empirical studies analysing the effects of incentives on physical investments, the literature is far from a consensus. Lee (1996), in a work for the manufacturing sector in South Korea, states that tax incentives positively affect output growth rates by stimulating capital accumulation. However, Klemm and Parys (2012) report that tax incentives have significant effects on attracting foreign investment, whereas they do not robustly affect total private investment. Two papers concerning with Italy's Law 488/1992 have different results. Bronzini and de Blasio (2006) divide firms into two categories; subsidized firms are supported firms by incentives and unsubsidized firms are rejected ones. They argue that an increase in investment by subsidized firms cannot be considered additional if unsubsidized firms are crowded out by subsidized firms and also the increase in investments now through the incentives is counterbalanced by a decrease in capital accumulation of subsidized firms in the future. Nevertheless, Bernini and Pellegrini (2011) find larger effects of subsidies on capital accumulation, when compared with Bronzini and de Blasio (2006). They state that the average increase in assets is positive and significant for subsidized firms. Two studies on Turkey report mixed results. Ay (2005) finds positive effects of incentives on fixed capital investments in Turkey. However, Ersel and Filiztekin (2005) examine the effects of investment incentives on the growth of investment volume in the manufacturing industry in Turkey for the period 1980-2000 using data from 16 sectors and report insignificant effects on the sectoral investment.

Luger (1984) is one of the seminal papers in the early literature, which studies the secondary effects of investment incentives. He concentrates on employment effects of investment incentives, and finds that investment incentives displace jobs by the help of substitution effect, which is more than newly created jobs via scale effect. He also states that investment incentives reallocate jobs between regions and sectors, and they increase employment only for specific industries and areas. Using aggregate annual data for manufacturing sector in Cape Breton region, for 1962-1984 periods, Daly et al. (1993) investigate the effects of the Canadian Cape Breton Investment Tax Credit programme on manufacturing and conclude that tax incentives for capital investment are not a good way of promoting employment in Canada. Similarly, Ersel and Filiztekin (2005) conclude that investment incentives are not effective in promoting employment in the manufacturing industry in Turkey for the period 1980-2000. Driehuis and van den Noord (1988) study the effects of investment incentives on employment in the Netherlands. This study shows that employment is negatively affected by the investment incentives. Also they state that capital-intensive sectors are much more negatively affected than labour-intensive sectors.

Using annual data for the 1978-1989 period, Schalk and Untiedt (2000) find positive effects of investment incentives on employment for 327 cross-regional units for the manufacturing industry in West Germany. Yavuz (2010) employs Turkish industry 
and investment incentive data for 1980-2008 period, and finds that investment incentives have positive impact on employment. Using Turkish provincial data for 2001, Yavan (2011) investigates the effects of investment incentives on regional economic development in Turkey. He concludes that employment increases by the help of the investments, which implicitly increases the economic growth of that province.

Large number of studies also examines the effects of incentives on productivity. Lee (1996) finds that tax incentives do not significantly affect TFP growth for the South Korean manufacturing industry. Similarly, Daly et al. (1993) find that total factor productivity is not affected by investment incentives in Cape Breton manufacturing industry in Canada. Schalk and Untiedt (2000) state that labour productivity changes in supported regions are negligible; investment incentives are not effective on reducing interregional productivity differences in manufacturing industry in West Germany. Harris and Trainor (2005) report that Selective Financial Assistance (SFA) in Northern Ireland affects the level of production in manufacturing industry positively, and capital subsidies have more positive impacts on total factor productivity than the other types of subsidies. Bernini and Pellegrini (2011) conclude that the impact of Law 488 significantly reduces total productivity growth and labour productivity for subsidized firms probably because firms are inclined to lower productivity projects due to the monetary incentives and also increase the number of new employees to raise the probability of being subsidized. Skuras et al. (2006) examine the impact of regional capital subsidies on productivity growth of food and beverage industry in Greece and find that since these incentives are usually directed to low-productivity projects, incentives only have substitution effects and do not create additional investment. Similarly, Harris and Robinson (2005) investigate the productivity growth effects of investment incentives in UK manufacturing sectors for the 1990s and find that assisted firms make an important change in terms of labour productivity whereas firms experiencing low total factor productivity substitute capital for labour.

Ersel and Filiztekin (2005) report that investment incentives are not significantly correlated with the total factor productivity in manufacturing sector in Turkey. A more recent study concerning structural change and industrial policy in Turkey, Atiyas and Bakis (2013) claim that improvements in labour productivity is achieved through the reallocation of employment from low to high productivity industries. However, they argue that investment incentive system in Turkey is weak since it does not evaluate the impact of the various components.

\section{Methodology and Data}

Our study uses a growth accounting framework assuming a constant returns to scale production function. Growth accounting analysis precedes the theoretical contributions to growth theory by Solow (1956) and Swan (1956), and a large number of studies including (Lee, 1996; Barro, 1999; Crafts and Mills, 2005; and Baier et al., 2006) also succeeded them. The following production function is employed in this study.

$$
Q_{i}=F\left(A_{i}, K_{i}, H_{i}, L_{i}\right)
$$


where $A_{i}$ is the level of technology, $Q_{i}$ is the value added, $K_{i}$ is the physical capital, $H_{i}$ is the human capital, and $L_{i}$ is the labour input used in sector $i$. We simplify the production function in terms of per labour input, then the equation of production function becomes as follows:

$$
q_{i}=f\left(A_{i}, k_{i}, h_{i}\right)
$$

$q_{i}=Y_{i} / L i($ labour productivity of sector $i$ )

$k_{i}=K_{i} / L i$ (capital intensity of sector $i$ )

$h_{i}=H_{i} / L i$ (level of human capital stock per labour input)

$A_{i} \quad($ level of technology in the sector $i)$

By using the Equation 2 and growth accounting framework, we can find the following equation:

$$
\dot{q}_{i} / q_{i}=\dot{A}_{i} / A_{i}+\alpha_{K} \dot{k}_{i} / k_{i}+\alpha_{H} \dot{h}_{i} / h_{i}
$$

where $\alpha_{\kappa}$ and $\alpha_{H}$ denote elasticity of output with respect to $\mathrm{K}$ and $\mathrm{H}$, respectively. In this equation, we find the labour productivity growth by the sum of the growth of technology and the growth of physical and human capital stocks.

Due to the lack of data on sectoral human capital stock data, as in Lee (1996), we consider the sum of $\dot{A}_{i} / A_{i}$ and $\alpha_{H} \dot{h}_{i} / h_{i}$ as growth of total factor productivity (TFP), so Equation 3 becomes like that:

$$
\dot{q}_{i} / q_{i}=\alpha_{K} \dot{k}_{i} / k_{i}+T \dot{F P} P_{i} / T F P_{i}
$$

We can follow the framework described above to explain the growth of sectoral output. As a developing country, most of the Turkish manufacturing industries are supposed to have had initial output and capital stocks that are below the steady-state ones. Thus, the sectoral output grows as the sector accumulates more physical and human capital stocks to achieve its steady-state output level. In the neoclassical growth model, both physical and human capital stock variables and control or policy variables are related to the growth rate of output per worker. These variables are supposed to affect the level of steady-state output and accordingly influence the growth per worker during the transition period. Thus, the initial level of capital stocks affects the growth rates of output and capital stock accumulation. The control variables, then, such as government investment incentive policies and exposure to the foreign trade, may impact growth rates of capital stocks and output by affecting both the steady-state level of capital stocks and the speed of capital accumulation.

An implementation of the Solow-type neoclassical growth model is employed in this study, primarily developed by Lee (1996), to find out the impact of investment incentives on the growths of labour productivity, capital intensity, employment, and total factor productivity. The equation of our model is as follows:

$$
Y_{i t}=\beta_{i t}+\gamma X_{i t}+\phi Z_{i t}+\sigma M_{i t}+e_{i t}
$$

$i=1,2, \ldots, \mathrm{n}$ denotes sectors

$t=1,2, \ldots, \mathrm{t} \quad$ denotes periods 
where, $Y_{i t}$, the dependent variable, is stated as the growth rates of labour productivity or capital stock or sectoral employment or TFP in the model. The vector of independent variables, $X_{i t}$ denotes initial levels of state variables such as labour productivity and capital intensity, $Z_{i t}$ denotes a number of investment incentive variables, and $M_{i t}$ denotes other macroeconomic variables.

Labour productivity $\left(q_{i}\right)$, is calculated as the ratio of value added to total work hour, and likewise capital intensity $\left(k_{i}\right)$ is calculated dividing sectoral capital stock by total work hour. We calculate two of our dependent variables, the growth of labour productivity and capital intensity for each year and each sector. Our third dependent variable, the growth of employment, is measured by total hours worked in each sector for that period.

The fourth dependent variable, growth of total factor productivity, is calculated by reversing the Equation 4 in the following way ${ }^{1}$.

$$
\operatorname{TFP} / T F P_{i}=\dot{q}_{i} / q_{i}-\alpha_{K} \dot{k}_{i} / k_{i}
$$

In our main Equation 5, $X_{i t}$ denotes the initial state variables employed in the estimates. They include logarithms of initial state values of value added per work hour $\left(q_{i t}\right)$ and capital stock per work hour $\left(k_{i t}\right)$. Our second set of independent variables $\left(Z_{i t}\right)$ is two different measures of investment incentive variables, and we employ each of them in our models sequentially. One of these variables is INFTI, which is the ratio of incentive supported fixed investment volume to the total actual investment volume. The other incentive variable, INFVA, is the ratio of incentive supported fixed investment to the value added volume.

Third type of independent variables $\left(M_{i}\right)$ utilized in the estimates is other macroeconomic variables. We named them as EXPV, IMPV, and INPT, which account for the ratios of sectoral export volume and sectoral import volume to value added volume, and the logarithm of total actual input volume, respectively.

We employ a panel data on sixteen manufacturing industry sectors in Turkey. Our classification of sectors in manufacturing industry is mainly based on SITC Rev 2. with some modifications and it is shown in Table 1.

Data on investment incentives are retrieved from the Treasury Department of Turkey. Number of investment incentives certificates accounts for the documents taken by the firms from government agencies to benefit from the incentives. Data on fixed investment, imported machinery equipment, and employment regarding incentives are planned/expected/ex-ante quantities that would be realized by incentive certificated investments.

Sectoral data on manufacturing industries in Turkey are obtained from the Annual Manufacturing Industry Statistics (for the years between 1981 and 2001) and Annual Industry and Service Statistics (for the years between 2003 and 2009) from the Turkish Statistical Institute. For the year 2002, the Turkish Statistical Institute did not publish annual statistics, so we have no data for that year. Data on other macroeconomic variables are retrieved from the Ministry of Development and Ministry of Economy of Turkey.

1 To estimate capital stock series, we follow the methods developed by Hall and Jones (1999) and OECD's delayed retirement pattern as in Saygili et al. (2005). 


\begin{tabular}{|l|l|}
\hline Code & Sector Name \\
\hline $\mathbf{1}$ & Food and Beverages \\
\hline $\mathbf{2}$ & Textiles and Clothing \\
\hline $\mathbf{3}$ & Forestry Products \\
\hline $\mathbf{4}$ & Paper \\
\hline $\mathbf{5}$ & Leather and Leather Products \\
\hline $\mathbf{6}$ & Rubber \\
\hline $\mathbf{7}$ & Chemicals \\
\hline $\mathbf{8}$ & Glassware \\
\hline $\mathbf{9}$ & Iron and Steel \\
\hline $\mathbf{1 0}$ & Non-Ferrous Metals \\
\hline $\mathbf{1 1}$ & Vehicles \\
\hline $\mathbf{1 2}$ & Metallic Goods \\
\hline $\mathbf{1 3}$ & Measuring Devices \\
\hline $\mathbf{1 4}$ & Machinery \\
\hline $\mathbf{1 5}$ & Electrical Machinery \\
\hline $\mathbf{1 6}$ & Cement, Clay, Ceramics Products \\
\hline
\end{tabular}

Source: Turkish Statistical Institute

Unless otherwise stated, we employ all variables in the estimates in constant (2005) Turkish Liras. Current values of various macroeconomic variables are deflated using sectoral producer price index (PPI) and investment related variables are deflated using investment deflators. Descriptive statistics of all variables used in this work is reported in Table 2.

Our model is first estimated by using the WLS (Weighted Least Squares) and then the system GMM (Generalized Method of Moments) methods. We use WLS instead of OLS (Ordinary Least Squares) to overcome cross-equation heteroscedasticity problem, which provides us more precise and consistent results. Variables are weighted by sectors in our estimations, and we use the absolute values of the residuals without constant.

GMM estimators are frequently used in the literature to overcome the problems like heteroscedasticity, endogeneity, fixed effect, over-identification, and validity. Baum et al. (2003) state that heteroscedasticity is an omnipresent problem in empirical works, and using GMM is a more efficient way of handling heteroscedasticity problem than instrumental variable (IV) estimator. Bazzi and Clemens (2009) argue that researchers of growth theory use complementary methods of GMM to assess instrument strength. Before testing for 
autocorrelation in GMM, validity of instruments is tested with the Hansen test. Baum et al. (2007) state that to over-identify restrictions, the Hansen J test is used, which makes the researcher more confident about the appropriateness of the instrument set. The number of groups should be more than or equal to the number of instruments, and we test the validity of instruments with the Hansen test. By the help of high p values in these tests in our estimations, we can conclude that our group of instruments is exogenous and our instruments are strong enough.

Table 2 | Summary Statistics

\begin{tabular}{|l|c|c|c|c|c|}
\hline Variable & $\begin{array}{c}\text { Obser- } \\
\text { vations }\end{array}$ & Mean & Std. Dev. & Min & Max \\
\hline Labour Productivity Growth & 96 & 0.0184 & 0.10875 & -0.2155 & 0.3089 \\
\hline Capital Intensity Growth & 96 & 0.01526 & 0.07265 & -0.1995 & 0.1992 \\
\hline Employment Growth & 96 & 0.04371 & 0.07370 & -0.1113 & 0.3973 \\
\hline TFP Growth & 96 & 0.00913 & 0.10982 & -0.2382 & 0.32583 \\
\hline Iog (initial labour productivity) & 96 & 1.30602 & 0.28348 & 0.39883 & 2.00102 \\
\hline Iog (initial capital intensity) & 96 & 1.78138 & 0.37850 & 0.94492 & 2.64984 \\
\hline Iog (input value) (INPT) & 80 & 21.5152 & 1.41844 & 17.006 & 24.0296 \\
\hline Export / Value Added (EXPV) & 96 & 0.74318 & 0.73005 & 0.10132 & 4.8609 \\
\hline Import / Value Added (IMPV) & 96 & 1.71987 & 2.54770 & 0.05461 & 13.0165 \\
\hline Incentive / Investment (INFTI) & 96 & 3.41911 & 4.69210 & 0.06806 & 31.978 \\
\hline Incentive / Value Added (INFVA) & 96 & 0.43694 & 0.45498 & 0.02702 & 2.4698 \\
\hline
\end{tabular}

Source: Author's calculations

Besides Arellano-Bond test is applied both for fixed effects and residuals in differences to test for autocorrelation. We use both of these tests when estimating results; our data and estimations are valid regarding the tests for autocorrelation. AR (1) and AR (2) tests are Arellano-Bond tests for autocorrelation in our estimations, which are also provided by Stata. In all our estimations, AR (1) tests are significant, and AR (2) tests are insignificant. This means there is autocorrelation in AR (1); however, we observe no autocorrelation in first difference levels of AR (2).

\section{Empirical Results}

We investigate sixteen sectors of manufacturing industry in Turkey, and evaluate the impact of incentives on the growth rates of sectoral labour productivity, capital intensity, employment, and total factor productivity. The WLS and system GMM estimation techniques are applied to a panel data set over five-year periods. From 1981 to 2009, we have 6 five- 
year periods; the first period is composed of four years, the others are composed of five years (1981-1984, 1985-1989, 1990-1994, 1995-1999, 2000-2004, 2005-2009). We have 96 observations for each of our variables except the logarithm of input value, for which we have 80 observations, since we have no data for the last period for this variable.

Table 3 | Regression Results for the Growth Rate of Labour Productivity

\begin{tabular}{|c|c|c|c|c|}
\hline Independent Variable & 1 & 2 & 3 & 4 \\
\hline \multirow{2}{*}{ log (initial labour productivity) } & $-0.146^{* *}$ & $-0.148^{* *}$ & $-0.122^{* * *}$ & $-0.135^{* * *}$ \\
\hline & 0.056 & 0.059 & 0.038 & 0.038 \\
\hline \multirow{2}{*}{ log (initial capital intensity) } & $-0.133^{* *}$ & $-0.134^{* *}$ & $0.055^{*}$ & $0.063^{*}$ \\
\hline & 0.064 & 0.065 & 0.03 & 0.028 \\
\hline \multirow{2}{*}{ Export / Value Added } & 0.0004 & -0.0002 & -0.005 & -0.005 \\
\hline & 0.014 & 0.014 & 0.007 & 0.007 \\
\hline \multirow{2}{*}{ Import / Value Added } & -0.005 & -0.005 & $0.004^{*}$ & $0.004^{* *}$ \\
\hline & 0.011 & 0.011 & 0.003 & 0.002 \\
\hline \multirow{2}{*}{ Capital Intensity Growth } & $0.583^{* * *}$ & $0.586^{* * *}$ & 0.283 & 0.299 \\
\hline & 0.199 & 0.197 & 0.177 & 0.173 \\
\hline \multirow{2}{*}{ Incentive / Investment } & -0.001 & - & $-0.004^{* *}$ & - \\
\hline & 0.002 & - & 0.002 & - \\
\hline \multirow{2}{*}{ Incentive / Value Added } & - & -0.005 & - & $-0.043^{*}$ \\
\hline & - & 0.016 & - & 0.022 \\
\hline Estimation technique & WLS & WLS & GMM & GMM \\
\hline Number of observations & 96 & 96 & 96 & 96 \\
\hline Number of instruments & - & - & 17 & 17 \\
\hline AR (2) & - & - & 0.116 & 0.136 \\
\hline Hansen Test & - & - & 0.753 & 0.493 \\
\hline
\end{tabular}

Note: 1, 5 and 10 per cent levels of significance are denoted as $*^{* *},{ }^{* *}$, and ${ }^{*}$, respectively. Standard Error values are provided by below the coefficients.

Sector and year dummies are included for WLS, year dummies are included for GMM estimates.

Source: Author's calculations

Each of the two investment incentive variables is included into the model separately, and regression results in the WLS and system GMM techniques are displayed in Tables 3-6. First two columns of Table 3 present the WLS estimation results. Both of our initial state variables have significant and negative coefficients. As expectedly, these results imply that sectors with higher initial labour productivity and capital intensity experience 
lower labour productivity growth. Trade variables are not significant in these regressions. None of the incentive measures (INFTI and INFVA) seem to have effect on sectoral labour productivity growth. Growth accounting framework presented above implies that incentives can affect sectoral output growth through two channels: either through affecting capital accumulation or influencing total factor productivity. To understand whether incentives affect output growth through capital accumulation channel, we also add capital intensity growth in the estimates. Our results also indicate that capital intensity growth significantly raises labour productivity growth. Note that our results are fairly different from the Lee (1996) results on Korean manufacturing industries. The WLS results presented in Lee (1996) indicate that tax incentives raise productivity through increasing capital accumulation. These results most probably imply the importance in design and implementation of these incentives $^{2}$.

Last two columns of Table 3 report the system GMM results. As explained above, we regard the system GMM results more reliable. Insignificant AR (2) and Hansen test statistics indicate that we do not have second-order autocorrelation and our instruments are valid ${ }^{3}$. Unlike the WLS results, both of the incentives measures have now statistically significant and negative coefficients regardless of the exclusion of capital intensity growth in the estimates. One explanation for this result is that as we shall discuss shortly, incentives reduce capital intensity growth, which in turns reduce labour productivity. This explanation is also supported by the GMM results that when we included capital intensity growth in the labour productivity regressions, both the magnitude and the significance of the estimated coefficients on incentives are reduced.

The estimated positive relationship between sectoral imports and labour productivity growth in the system GMM estimations is an also interesting result. When an import share in a sector increases, the growth of value added per work hour increases. It is possible to explain that sectors with higher imports work with relatively higher level of capital intensity, which in turn raises total factor productivity growth and hence the growth rate of labour productivity increases.

Table 4 reports the effects of incentives on the growth rate of capital stock per work hour. The initial capital intensity level is strongly and negatively related with capital intensity growth in both of the estimation techniques. Similarly, initial labour productivity affects capital intensity growth negatively. Estimated coefficients on sectoral export shares are statistically significant and negative for the system GMM estimations. As a developing country with abundant labour resources, exports of Turkey are more likely to be labour-intensive. Thus, it is no surprise that sectoral exports levels are negatively associated with capital intensity ratios. When we compare the estimation results of the effects of export shares on the growth of labour productivity and capital intensity, we can conclude that it affects capital intensity growth negatively whereas it does not affect labour productivity growth.

2 Relatively a large literature exists on the efficiency of Korean industrial policies, see Amsden (1989) and World Bank (1993).

3 Note that to solve the problem of instrument proliferation we use "collapse" option as described in Roodman (2009). 
Table 4 | Regression Results for the Growth Rate of Capital Intensity

\begin{tabular}{|c|c|c|c|c|}
\hline Independent Variable & 1 & 2 & 3 & 4 \\
\hline \multirow{2}{*}{$\begin{array}{l}\text { log (initial labour } \\
\text { productivity) }\end{array}$} & $-0.088^{* * *}$ & $-0.093^{* * *}$ & -0.037 & $-0.049^{*}$ \\
\hline & 0.032 & 0.034 & 0.027 & 0.027 \\
\hline \multirow{2}{*}{ log (initial capital intensity) } & $-0.216^{* * *}$ & $-0.223^{* * *}$ & $-0.094^{* * *}$ & $-0.092^{* * *}$ \\
\hline & 0.029 & 0.029 & 0.021 & 0.021 \\
\hline \multirow{2}{*}{ Export/Value Added } & -0.008 & -0.011 & $-0.021^{* * *}$ & $-0.021^{* *}$ \\
\hline & 0.008 & 0.009 & 0.007 & 0.008 \\
\hline \multirow{2}{*}{ Import/Value Added } & -0.01 & $-0.011^{*}$ & -0.003 & -0.003 \\
\hline & 0.006 & 0.006 & 0.002 & 0.002 \\
\hline \multirow{2}{*}{ Incentive/Investment } & $-0.003^{* *}$ & - & $-0.002^{* *}$ & - \\
\hline & 0.001 & - & 0.001 & - \\
\hline \multirow{2}{*}{ Incentive/Value Added } & - & $-0.017^{*}$ & - & $-0.033^{* *}$ \\
\hline & - & 0.01 & - & 0.013 \\
\hline Estimation technique & WLS & WLS & GMM & GMM \\
\hline Number of observations & 96 & 96 & 96 & 96 \\
\hline Number of instruments & - & - & 16 & 16 \\
\hline AR (2) & - & - & 0.959 & 0.724 \\
\hline Hansen Test & - & - & 0.368 & 0.484 \\
\hline
\end{tabular}

Note: see Table 3.

Source: Author's calculations

The estimated coefficients on the incentives are significantly negative for both the WLS and system GMM estimations. Our results imply that investment incentives significantly reduce capital intensity growth. These results differ from Lee (1996), since he finds that incentives affect capital stock accumulation positively. However, our results are similar to the Bronzini and de Blasio (2006), who claim that since unsubsidized firms are eliminated by subsidized firms and the incentives affect the timing of the investment of subsidized firms, it is likely for a sector to accumulate even less physical capital in the long run.

Moreover, we expect that incentives are intended to encourage firms to invest more, and accumulate more capital. It is thus difficult to argue that recipients firms invest less after the incentives. However, the negative effects of incentives on capital intensity growth may be observed when the growth rate of labour is higher than the growth rate of capital stock. 
Then, we investigate the impact of investment incentives on the growth rate of employment. Table 5 reports the effects of incentives on the growth rate of sectoral employment. Estimated results on initial variables show that initial labour productivity and initial capital intensity do not significantly affect the employment growth. Statistically significant and positive estimated coefficients on sectoral trade variables indicate that both of the sectoral export and import shares raise employment growth. It is possible to argue that trade oriented sectors generate more jobs and imported investment equipment and intermediate goods also increase employment rates. In addition to the other control variables, we have the logarithm of sectoral input values in these estimations. Input value has no significant effect on growth rate of employment using both the WLS and the system GMM estimations ${ }^{4}$.

Table 5 | Regression Results for the Growth Rate of Employment

\begin{tabular}{|c|c|c|c|c|}
\hline Independent Variable & 1 & 2 & 3 & 4 \\
\hline \multirow{2}{*}{ log (initial labour productivity) } & 0.054 & $0.076^{*}$ & 0.061 & 0.042 \\
\hline & 0.042 & 0.043 & 0.039 & 0.032 \\
\hline \multirow{2}{*}{ log (initial capital intensity) } & 0.021 & 0.019 & -0.018 & -0.007 \\
\hline & 0.038 & 0.037 & 0.022 & 0.023 \\
\hline \multirow{2}{*}{ Export / Value Added } & $0.019 *$ & $0.02^{* *}$ & $0.026^{* *}$ & $0.025^{* *}$ \\
\hline & 0.01 & 0.01 & 0.011 & 0.011 \\
\hline \multirow{2}{*}{ Import / Value Added } & 0.01 & 0.008 & $0.008^{* *}$ & $0.007^{* *}$ \\
\hline & 0.01 & 0.01 & 0.003 & 0.003 \\
\hline \multirow{2}{*}{ log (input value) } & -0.007 & -0.014 & -0.005 & -0.002 \\
\hline & 0.023 & 0.023 & 0.005 & 0.004 \\
\hline \multirow{2}{*}{ Incentive / Investment } & -0.0004 & - & $-0.003^{* *}$ & - \\
\hline & 0.001 & - & 0.001 & - \\
\hline \multirow{2}{*}{ Incentive / Value Added } & - & 0.012 & - & -0.008 \\
\hline & - & 0.01 & - & 0.022 \\
\hline Estimation technique & WLS & WLS & GMM & GMM \\
\hline Number of observations & 80 & 80 & 80 & 80 \\
\hline Number of instruments & - & - & 15 & 15 \\
\hline AR (2) & - & - & 0.54 & 0.752 \\
\hline Hansen Test & - & - & 0.581 & 0.484 \\
\hline
\end{tabular}

Note: see Table 3.

Source: Author's calculations

4 If we rerun the same regressions without the input value variable for 96 observations, we obtain almost identical results for our incentives variables. 
Our estimations results suggest that none of the incentive variables seems to have any significant impact on the employment growth when we apply WLS. Since our GMM estimations indicate that while INFTI negatively affects sectoral employment growth, INFVA does not affect it significantly. Thus, we fail to find any evidence that incentives are effective in raising sectoral employment. One possible explanation for these results is that incentives may cause job displacement within the sector rather than producing new jobs. Another explanation might be the case that incentives are more likely to raise imported machinery equipment rather than employment. Simple statistics for the investment incentive certificates indicates that the proportion of imported machinery equipment to fixed investment for the Turkish manufacturing industry increases to 64 per cent in the 2000 s from 25 per cent for the 1980s. Therefore, we might easily conclude that investment incentives are especially used to import machinery equipment. It is then no surprise that investment incentives do not raise the level of sectoral employment.

Table 6 | Regression Results for the Growth Rate of Total Factor Productivity

\begin{tabular}{|c|c|c|c|c|}
\hline Independent Variable & 1 & 2 & 3 & 4 \\
\hline \multirow{2}{*}{$\begin{array}{l}\text { log (initial labour } \\
\text { productivity) }\end{array}$} & $-0.163^{* * *}$ & $-0.17^{* * *}$ & $-0.13^{* * *}$ & $-0.142^{* * *}$ \\
\hline & 0.054 & 0.056 & 0.036 & 0.037 \\
\hline \multirow{2}{*}{ log (initial capital intensity) } & $-0.146^{* * *}$ & $-0.149^{* * *}$ & $0.079 * * *$ & $0.086^{* * *}$ \\
\hline & 0.049 & 0.049 & 0.022 & 0.023 \\
\hline \multirow{2}{*}{ Export / Value Added } & -0.005 & -0.006 & -0.002 & -0.003 \\
\hline & 0.014 & 0.014 & 0.007 & 0.006 \\
\hline \multirow{2}{*}{ Import / Value Added } & -0.003 & -0.002 & $0.008^{*}$ & $0.008^{* *}$ \\
\hline & 0.011 & 0.011 & 0.004 & 0.003 \\
\hline \multirow{2}{*}{ Incentive / Investment } & -0.0005 & - & $-0.004^{*}$ & - \\
\hline & 0.002 & - & 0.002 & - \\
\hline \multirow{2}{*}{ Incentive / Value Added } & - & -0.0078 & - & -0.037 \\
\hline & - & 0.016 & - & 0.022 \\
\hline Estimation technique & WLS & WLS & GMM & GMM \\
\hline Number of observations & 96 & 96 & 96 & 96 \\
\hline Number of instruments & - & - & 16 & 16 \\
\hline $\operatorname{AR}(2)$ & - & - & 0.205 & 0.274 \\
\hline Hansen Test & - & - & 0.369 & 0.231 \\
\hline
\end{tabular}

Note: see Table 3.

Source: Author's calculations 
Since the government aims to increase employment in targeted sectors and regions by providing investment incentives, we can argue that investment incentives are far away from achieving these targets. Comparing our results with the literature, our results are consistent with the conclusions for Canada and the Netherlands. As discussed above, incentives have no significant effect on employment for Canada, whereas they reduce employment in the Netherlands.

Table 6 reports the results for the sectoral TFP growth. Initial value added per work hour significantly reduce the growth rate of total factor productivity for both of the methods. As expectedly, the GMM estimations show that initial state of capital stock per work hour has a significant and positive effect on total factor productivity growth. While export shares do not affect it, import shares raise the growth rate of total factor productivity probably due to the access to the better capital goods and inputs. Although the estimated coefficient on INFTI is significantly negative at the $10 \mathrm{per}$ cent level, the estimated coefficient on INFVA is not statistically significant. Thus, our results indicate that incentives do not improve TFP.

It is not surprising to have non-positive effects of investment incentives on TFP because incentives are mainly intended to channel to the less developed regions within the design of the Turkish incentives system. Moreover, if jobs are actually moved to the lowproductivity sectors and regions, or if incentives are mostly designed to assist firms with low productivities, or if capital is substituted by labour probably due to relatively cheaper capital, we can get similar effects. Our findings for the effect of investment incentives on TFP are similar to the experiences of other countries. A number of studies discussed above report the non-positive effects of incentives on TFP for Greece, South Korea, Canada, and the UK.

\section{Conclusion}

Our study investigates the impacts of investment incentives, measured by two different variables, on the growth rates of labour productivity, capital intensity, employment and total factor productivity for the sixteen manufacturing sectors in Turkey between the years 1981 and 2009. Our panel dataset consists of six five-year periods and employ both the WLS and system GMM estimation techniques. Our GMM estimations suggest that while they reduce the growth rate of labour productivity and capital intensity, investment incentives do not exert any positive and significant impact on total factor productivity and employment.

There can be a couple of explanations of the negative effects of investment incentives on the growth of labour productivity and capital intensity. For instance, since our investment incentive measures are actually ex-ante figures that are expected to be realized in the coming periods, our results might be altered if we had data on realized values for the investment incentives. Moreover, since these incentives measures are mostly directed to low-returns regions, it is no surprise to have undesirable effects on these variables due to the overall unfavourable conditions in those regions.

Investment incentives are supposed to attract new investments to increase capital accumulation and then employment. As discussed above, however, if subsidized firms crowd 
out unsubsidized firms, and if incentives mostly alter the timing of the investment taken by the firms, then it is possible that overall effect of incentives on the capital accumulation can be negative over time. Further, our raw data also indicate that incentives are more likely to raise imported machinery rather than employment.

Our results also show that incentives fail to raise sectoral total factor productivity. One explanation might be that incentive-recipient firms may be actually inclined to invest in projects with a lower than average productivity for some reasons such as directing investments to less developed regions. Furthermore, our findings may be the artifact of the case that these incentives are actually supporting old and declining sectors in these countries.

When we compare the effects of investment incentives for the Turkish manufacturing industries with the successful countries' (such as South Korea, Germany and China) manufacturing sectors, one may easily argue that since these successful countries have better macroeconomic environment and more effective government, investment incentives are actually effectively designed and implemented in these countries. We believe that since our conclusions on these variables for Turkey are mostly consistent with the experience of other countries, our discussions in this paper on the potential causes and implications of inefficient investment incentives also can be applied to the other countries.

\section{References}

Alam, K. F., Stafford, L. W. T. (1985). Tax Incentives and Investment Policy: A Survey Report on the United Kingdom Manufacturing Industry. Managerial and Decision Economics, 6(1), 27-32, https://doi.org/10.1002/mde.4090060106

Amsden, A. H. (1989). Asia's Next Giant: South Korea and Late Industrialization. New York: Oxford University Press. ISBN 978-0195076035.

Atiyas, I.., Bakis, O. (2013). Structural Change and Industrial Policy in Turkey. TUSIAD - Sabanci Universitesi Rekabet Forumu. Working Paper No. 2013-3.

Ay, H. M. (2005). Yatirim Tesviklerinin Sabit Sermaye Yatirimlari Uzerindeki Etkisi (The Impact of Investment Incentives on Fixed Capital Investments). Selçuk Universitesi Karaman iktisadi ve Idari Bilimler Dergisi, 5(2), 176-184.

Baier, S. L., Dwyer, G. P., Tamura, R. (2006). How Important Are Capital and Total Factor Productivity for Economic Growth? Economic Inquiry, 44(1), 23-49. Available at: http:// ssrn.com/abstract=906366, https://doi.org/10.1093/ei/cbj003

Barro, R. J. (1999). Notes on Growth Accounting. Journal of Economic Growth, 4(2), 119-137, https://doi.org/10.1023/A:1009828704275

Baum, C. F., Schaffer, M. E., Stillman, S. (2003). Instrumental Variables and GMM: Estimation and Testing. The Stata Journal, 3(1), 1-31.

Baum, C. F., Schaffer, M. E., Stillman, S. (2007). Enhanced Routines for Instrumental Variables/ GMM Estimation and Testing. The Stata Journal, 7(4), 465-506.

Bazzi, S., Clemens, M. A. (2009). Blunt Instruments: A Cautionary Note on Establishing the Causes of Economic Growth. Center for Global Development. Working Paper No. 171. 
Bernini, C., Pellegrini, G. (2011). How Are Growth and Productivity in Private Firms Affected by Public Subsidy? Evidence from a Regional Policy. Regional Science and Urban Economics, 41(3), 253-265, https://doi.org/10.1016/j.regsciurbeco.2011.01.005

Bronzini, R., de Blasio, G. (2006). Evaluating the Impact of Investment Incentives: The Case of Italy's Law 488/1992. Journal of Urban Economics, 60(2), 327-349, https://doi. org/10.1016/j.jue.2006.03.005

Buss, T. F. (2001). The Effect of State Tax Incentives on Economic Growth and Firm Location Decisions: An Overview of the Literature. Economic Development Quarterly, 15(1), 90-105, https://doi.org/10.1177/089124240101500108

Cannari, L., D'Aurizio, L., de Blasio, G. (2006). The Effectiveness of Investment Subsidies: Evidence from Survey Data. Bank of Italy. Occasional Paper No. 4, https://doi.org/10.2139/ssrn.1014556

Chen, Y., He, Z., Zhang L. (2015). The Effect of Investment Tax Incentives: Evidence from China's Value-Added Tax Reform. Available at: http://ssrn.com/abstract=1918579, https://doi. org/10.2139/ssrn.1918579

Crafts, N., Mills, T. C. (2005) TFP Growth in British and German Manufacturing, 1950-1996. The Economic Journal, 115(505), 649-670, https://doi. org/10.1111/j.1468-0297.2005.01013.x

Daly, M., Gorman, I., Lenjosek, G., Macnevin, A., Phiriyapreunt, W. (1993). The Impact of Regional Investment Incentives on Employment and Productivity - Some Canadian Evidence. Regional Science and Urban Economics, 23(4), 559-575, https://doi. org/10.1016/0166-0462(93)90047-I

Driehuis, W., van den Noord, P. J. (1988). The Effects of Investment Subsidies on Employment. Economic Modelling, 5(1), 32-40, https://doi.org/10.1016/S0264-9993(98)90005-0

Ersel, H., Filiztekin, A. (2005). Incentive or Compensation? Government Support for Private Investment in Turkey. The Egyptian Center for Economic Studies. Working Paper No. 107.

Hall, R. E., Jones, C. I. (1999). Why Do Some Countries Produce so much more Output per Worker than Others? The Quarterly Journal of Economics, 114(1), 83-116, https://doi. org/10.1162/003355399555954

Harris, R., Robinson, C. (2005). Impact of Regional Selective Assistance on Sources of Productivity Growth: Plant-Level Evidence from UK Manufacturing, 1990-98. Regional Studies, 39(6), 751-765, https://doi.org/10.1080/00343400500213648

Harris, R., Trainor, M. (2005). Capital Subsidies and Their Impact on Total Factor Productivity: Firm-Level Evidence from Northern Ireland. Journal of Regional Science, 45(1), 49-74, https://doi.org/10.1111/j.0022-4146.2005.00364.x

Klemm, A., Van Parys, S. (2012). Empirical Evidence on the Effects of Tax Incentives. International Tax and Public Finance, 19(3), 393-423, https://doi.org/10.1007/s10797-011-9194-8

Lee, J. W. (1996). Government Interventions and Productivity Growth. Journal of Economic Growth, 1(3), 391-414, https://doi.org/10.1007/BF00141045

Luger, M. I. (1984). Investment Incentives and the Demand for Labor in United-States Regions. Regional Science and Urban Economics, 14(4), 481-503, https://doi.org/ 10.1016/0166-0462(84)90028-0

Roodman, D. (2009). A Note on the Theme of too Many Instruments. Oxford Bulletin of Economics and Statistics, 71(1), 135-158, https://doi. org/10.1111/j.1468-0084.2008.00542.x 
Saygili, S., Cihan, C., Yurtoglu, H. (2005). Turkiye Ekonomisinde Sermaye Birikimi, Verimlilik ve Buyume (1972-2003): Uluslararasi Karsilastirma ve AB'ye Yakinsama Sureci (2014) TUSIAD Buyume Stratejileri Dizisi (6), Ankara:TUSIAD. (Saygili, S., Cihan, C., Yurtoglu, H. (2005). Capital Accumulation, Productivity and Growth in the Turkish Economy (1972-2003): International Comparison and Convergence Process to the EU. TUSIAD Buyume Stratejileri Dizisi (6), Ankara: TUSIAD)

Schalk, H. J., Untiedt, G. (2000). Regional Investment Incentives in Germany: Impacts on Factor Demand and Growth. The Annals of Regional Science, 34(2), 173-195, https://doi. org/10.1007/s001689900008

Skuras, D., Tsekouras, K., Dimara, E., Tzelepis, D. (2006). The Effects of Regional Capital Subsidies on Productivity Growth: A Case Study of the Greek Food and Beverage Manufacturing Industry. Journal of Regional Science, 46(2), 355-381, https://doi. org/10.1111/j.0022-4146.2006.00445.x

Solow, R. M. (1956). A Contribution to the Theory of Economic Growth. Quarterly Journal of Economics, 70(1), 65-94, https://doi.org/10.2307/1884513

Swan, T. W. (1956). Economic Growth and Capital Accumulation. Economic Record, 32(2), 334-61, https://doi.org/10.1111/j.1475-4932.1956.tb00434.x

Tekin, A. (2006). Vergi Tesvikleri ve Ekonomik Etkileri. Dumlupinar Universitesi Sosyal Bilimler Dergisi (16), 301-316. (Tax Incentives and Its Economic Effects).

World Bank. (1993). The East Asian Miracle: Economic Growth and Public Policy. New York: Oxford University Press.

Yavan, N. (2011). Tesviklerin Bolgesel Ekonomik Buyume Uzerindeki Etkisi: Ampirik Bir Analiz. Ekonomik Yaklasim, 22(81), 65-104. (The Impact of Investment Incentives on Regional Economic Growth: An Empirical Analysis).

Yavuz, A. (2010). Bir Maliye Politikasi Araci Yatirim Tesviklerinin Rekabet Kosullari Altinda Ozel Kesim Yatirimlari ve Istihdam Uzerine Etkisi: Ekonometrik Bir Analiz. Suleyman Demirel Universitesi Iktisadi ve Idari Bilimler Fakultesi Dergisi, 15(1), 83-101. (As a Fiscal Policy Instrument, the Effect of Investment Incentives to Private Sector and Employment Under Conditions of Competition: an Econometrical Analysis). 